\title{
Factors Influencing Students' Well-being on Educational Outcomes in the Indonesian Railway Polytechnic
}

\author{
Ainun Fikria, ainun@ppi.ac.id, Politeknik Perkeretaapian Indonesia Madiun, Indonesia \\ Akhyat Hilmi, akhyat.hilmi@ gmail.com, Surabaya, Indonesia \\ Afita Prastiwi, afita.prastiwi@hangtuah.ac.id, Universitas Hangtuah, Surabaya, Indonesia
}

\begin{abstract}
Students' well-being among Indonesian scholars might be still unpopular as this topic could lead a blundered result in certain areas of disciplines. Yet, this topic is essential to reveal as it can be one of the indicators which can be taken into account on measuring the workload of students enrolling this state-owned institution. Not only that, this also might be an eminent output indicator for the quality of education specifically on educational outcomes. The instruments occupied in this study were interviews and surveys. Students and alumni of the polytechnic were asked to participate in this study and several key figures as well. This study used a mixed method research approach, which is widely accepted because it includes both qualitative and quantitative components. The results showed that the quality of student well-being in an emotional, social and school dimension of student PPIM is relatively in good level. Thus, the main factors influencing student's well-being which affects educational outcomes in PPIM were academic efficacy, self-efficacy and support from their friends. Hence, with the tight schedule and tough physical activity, the institution should pay attention on a psychological aspect.

Keywords: Students’ Well-being, Academic Outcomes, Factors influencing, Indonesian Railway Polytechnic.
\end{abstract}

\section{INTRODUCTION}

In educational practice, the essence of educational background as a foundation to get right and proper jobs are still debatable. Several pedagogical experts in graduate employability (Abd Majid et al, 2020; Boahin \& Hofman, 2013; Holmes, L. 2013) argued that skills and knowledge gained during studying in higher education stages have positive relationships with employability. However, another perspective about linearity of education and employability is not significant which was revealed by Yusof \& Jamaluddin (2017). This study unveiled that graduate employability does not solely depend on students' academic background but relies on their

136 | IJET| Volume. 10, Issue 2. December 2021 Copyright 2021 Ainun Fikria, Akhyat Hilmi, and Afita Prastiwi are licensed under Creative Commons AtrributionShareAlike 4.0 International License. 
preparedness in the workforce with their personal factors, organizational experiences, and the situation of the labor force itself.

Students' personal factors may relate to psychological, social and cognitive aspects. It is widely discussed under the umbrella of the well-being state. The definition of well-being itself has expanded into numerous fields because it comprises all aspects of healthy and successful living, including psychological, economic, physical, and other domains (Arslan and Coşkun 2020, Govorova, Benítez et al. 2020). Whereas student's well-being is "psychological, cognitive, social and physical functioning and capabilities that students need to live a happy fulfilling life" (OECD 2017). The psychological dimension comprises a sense of purpose in life, self-awareness, affective states and emotional strength which are reinforced by self-esteem, motivation, resilience, selfefficacy, hope and optimism. In a discussion of the social dimension, PISA adopted the Polard and Lee model which includes students' relationship with family, teachers and peers and sense belonging (Pollard and Lee 2003). To avoid broadening discussion, this study is a focus on discussing emotional, social and school dimension of students' well-being by considering the learning circumstance of PPIM.

Emotional well-being is described by Schutte et al. as "an affective subjective experience comprising domains such as mood and self-esteem" (Schutte, Malouff et al. 2002). The lack of behavior problems such as aggressive and impulsive behavior, withdrawal, sadness, anxiety, and somatic difficulties is another approach to think about emotional well-being. (Parhiala, Torppa, and colleagues, 2018). Parhiala goes on to say that four indicators are used to quantify this dimension of happiness: pupils' self-reported school fatigue, self-esteem, and externalizing and internalizing behavior problems. Out of these four indicators, motivation (Hagenauer \& Hascher, 2014; Pekrun,1992, 2006, 2009) and mood as well as self-esteem, are also associated with emotion at schools (Schutte, Malouff et al. 2002).

Emotional as well as social well-being are important matters associated with school life. Dacey recommends SEL, social emotional learning, as a holistic approach in education that fosters students to understand themselves and be able to cope with the difficulty in the future life (Dacey, Fiore et al., 2016). Good social and emotional skills will help the students to face the challenge of a socio-economic climate in the future life (OECD 2015).

Indonesian Railway Polytechnic is a boarding school focusing on developing vocational education where the learning process gradually occurs a whole day. Therefore, the students have a tight schedule, depending on the school rules. Thus, this school environment is the main point that influences student's well-being regarding that students of PPIM spend almost all their time at school environment rather than at home. Konu and Rimpela developed a model school well-being based on Allardt's well-being concept (Konu and Rimpelä 2002).

137 | IJET| Volume. 10, Issue 2. December 2021

Copyright 2021 Ainun Fikria, Akhyat Hilmi, and Afita Prastiwi are licensed under Creative Commons Atrribution-

ShareAlike 4.0 International License 


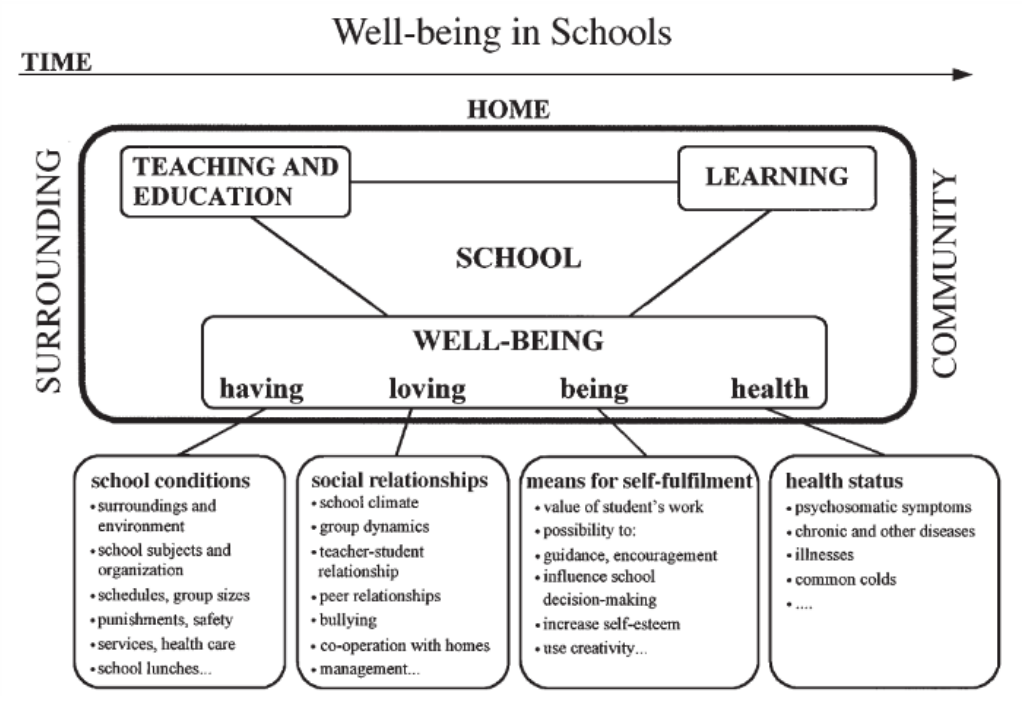

Figure 1.1 Allardt's Well-Being Concept

Allardt's well-being indicators are allocated into three categories. First, 'having' which indicates school conditions (school well-being). The second is 'loving' which refers to social relationships' aspect (social well-being). The third is 'being' that denotes self-fulfillment (emotional well-being).

Moving further on the studying process, the students' condition, particularly their psychological circumstances during their studies, play a role in their academic success. This is in accordance with the findings of various studies looking for positive correlations between psychological fitness and academic achievement. Quinn \& Duckworth, (2007); Purtaghi \& Pakpour, (2014); Tabbodi et al, (2015) have all stated that academic accomplishment and personal well-being are correlated. Subjective and objective indicators of competencies, perceptions, expectations, and life conditions can be used to measure this phenomenon of a dynamic state that occurs among students related to their ability and opportunity to achieve their personal and social goals, which involves multiple dimensions of students' lives (Borgonovi and Pál 2016). Subjective well-being refers to how people assess their own lives. Subjective wellbeing (SWB) was defined by Zhang and Renshaw as "a person's self-perceptions of so-called "positive" interior experiences, which are not always positive."

Subjective well-being (SWB) in school indicating how students experience and subjectively assess their school lives is a key indicator revealing how the students adapt to school life (Tian, Wang et al. 2015, Yang, Tian et al. 2019). There has been a series of research conducted to reveal that there is a positive relationship between students' well-being and their academic achievement (Gutman \& Feinstein, 2008; Gutman, Brown, Akerman, \& Obolenskaya, 2009). Students' subjective well-being was reported to have a positive correlation to students' achievement (Putri, Agustina et al. 2019) (Arslan \& Duru, 2017; Shoshani \& Slone, 2013). Students 'subjective

137 | IJET | Volume. 10, Issue 2. December 2021 Copyright 2021 Ainun Fikria, Akhyat Hilmi, and Afita Prastiwi are licensed under Creative Commons AtrributionShareAlike 4.0 International License 
well-being has been assessed by various scales so far, for example Multidimensional Students' life Satisfaction Scale, Comprehensive Quality of Life Scale, the Quality of School Life Scale and PANAS (Tian, et all, 2015). Those scales have some components that reveal the factors related to student's subjective well-being, for example, PANAS measures affective component.

There have been numbers of research on factors influencing students' educational outcomes (KIRANA 2016, Prapdopo and Fariyanti 2016, Rahmayani 2017, TL, Widowati et al. 2017, Hartati and Anugrahwati 2019, Isnurani, Sastro et al. 2021). However, there is less empirical studies related to adult learners specifically from ministry-owned educational institutions discussing such topics related to students' well-being. A few of them are investigating the correlation between subjective well-being and academic achievement (Putri, Agustina et al. 2019), as well as studying the factors that influence college students' well-being (Dewi and Nasywa 2019, Rulanggi, Fahera et al. 2021). The last two studies were literature review. Therefore, it is valuable to conduct a study discover the factors influencing adult pupils' well-being on their future educational outcomes.

This study therefore is aimed to seek the predictors and strong factors about their psychological aspects in their academic output which will be focused on their academic progress and readiness entering the labor force. Moreover, there will be a multiple stage of selecting the variables as factors, the depth analysis will be taken by composing a systematic review to strengthen whether the selected factors will be measurable and representative or not.

\section{METHOD}

A case study technique was used in this study, which is a frequent methodology in educational settings (Merriam, 1998). A case study, according to Yin (2003), is a "complete research technique" for addressing the reasons or elements that influence the process of particular phenomena. Stake (1995) identified a case that should be considered an object while simultaneously emphasizing the process. Stake argues that a case study is better suited to a study program than a process of a specific event, but Yin feels that a case study is better suited to an evaluation study for a certain educational institution. The case study is also more "holistic, empirical, and emphatic," emphasizing that it is part of a larger research system, according to Stake.

This study used a mixed method or multi-method research approach, which is widely accepted because it combines qualitative and quantitative components. In research, the quantitative and qualitative methodologies are the most well-known. Each approach has its own set of flaws; however, by combining the two methods, known as mixed methods, more detailed, accurate, and comprehensive findings can be obtained as one method counteracts another (Terrel, 2012). According to Schulze (2003), integrating the two methodologies allows researchers to generate research results that are more in-depth, broad, and rich in information from diverse perspectives. Furthermore, Morse and Chung (2003) believe that a mixed method approach, rather than a

137 | IJET| Volume. 10, Issue 2. December 2021

Copyright 2021 Ainun Fikria, Akhyat Hilmi, and Afita Prastiwi are licensed under Creative Commons AtrributionShareAlike 4.0 International License 
quantitative or qualitative study design, allows for more proofs from various sources, resulting in deeper insights.

This research was conducted at Indonesian Railway Polytechnique Madiun. The convenience sampling method used in this research for this study will investigate the matter based on the subjective view of the respondent based on their experience. The respondents have given their approval in providing detail information needed. The total sample in this study is 98 respondents which consists of 57 students and 41 alumni.

In the quantitative phase, this study used an online survey to gain quantitative data through a questionnaire. The questionnaire which was an adaptation from BASWBSS (Tian, et all, 2015) consists of 17 statements related to their experience during study time at PPIM that reveal the school well-being, emotional well-being and social well-being based on the respondents' subjective thought. All the statement used 5-point Likert Scale labelled as follows:

Table 2. 1 Criteria of Likert Scale

\begin{tabular}{ll}
\hline Criteria & Scale \\
Strongly agree (SA) & 5 \\
Agree (A) & 4 \\
Neutral (N) & 3 \\
Disagree (D) & 2 \\
Strongly disagree (SD) & 1 \\
\hline
\end{tabular}

This data was analyzed using Likert scale to determine which variables can be measured quantitatively. After the results of student responses are obtained, then the data were analyzed to know students' responses score through the formula as Nazir (2005) implies the formula as follows below:

\section{Formula: T x Pn}

Note:

T : total respondent

Pn : The chosen Likert score

$\mathrm{Y} \quad$ : The highest score of Likert $\mathrm{x}$ total respondent $\mathrm{x}$ total response

$\mathrm{X} \quad$ : The lowest score of Likert $\mathrm{x}$ total respondent $\mathrm{x}$ total response

Interval formula $=100 /$ total score

Percentage formula $\%=$ Total Score $/$ Y x 100

The following criteria of score interpretation based on interval

$0 \%-19,99 \% \quad$ : strongly disagree

$20 \%-39,99 \% \quad:$ disagree

$40 \%-59,99 \% \quad$ : neutral

$60 \%-79,99 \% \quad$ : agree

137 | IJET| Volume. 10, Issue 2. December 2021

Copyright 2021 Ainun Fikria, Akhyat Hilmi, and Afita Prastiwi are licensed under Creative Commons AtrributionShareAlike 4.0 International License 
$80 \%-100 \% \quad$ : strongly agree

At the qualitative phase, a face-to-face semi-structured interview was conducted with two teachers and two counseling staffs of PPIM. They were interviewed about how they see the students, whether any problem with the students' performance, how they deal with the problem and ask them to give suggestions that will improve the aspect of students' well-being during the study period. The information from this interview is used to get more deeply held attitudes, values, beliefs, and assumptions concerning wellbeing in schools.

\section{RESULT}

The following is the finding that reveal the factors that influence the students' well-being on educational outcomes in The Indonesian Railway Polytechnic. This study gained students' responses 17 item of predicting factors of well-being which are classified into three parts. The first was used to gain students' experience responses toward the predicting factors of school well-being. Then, the second was used to gain students' response toward predicting factors experienced related to emotional well-being. Thus, the third was used to gain students' response toward predicting factors experienced regarding social well-being. This data of predicting factors of the three dimensions of well-being are then compared to seek for the strong prediction factors that affect students' well-being.

\section{School well being}

From the school well-being dimension questionnaire part, the students' responses toward the five prediction factors measured using Likert scale are presented as follows:

Table 3.1. The Result of School Well-Being Questionnaire

\begin{tabular}{|c|c|c|c|c|c|c|}
\hline No & Question & $\mathbf{S A}$ & $\mathbf{A}$ & $\mathbf{N}$ & $\mathbf{D}$ & SD \\
\hline 1 & $\begin{array}{l}\text { According to me, studying at PPI Madiun opens big } \\
\text { opportunity to improve my skill }\end{array}$ & 41 & 49 & 5 & 1 & 2 \\
\hline 2 & I feel overwhelmed at studying & 2 & 25 & 48 & 22 & 1 \\
\hline 3 & $\begin{array}{l}\text { I feel all the courses offered are fully relevant for my future } \\
\text { work }\end{array}$ & 24 & 52 & 16 & 5 & 1 \\
\hline 4 & $\begin{array}{l}\text { I feel there are some irrelevant courses taught at PPI } \\
\text { Madiun }\end{array}$ & 5 & 38 & 32 & 19 & 4 \\
\hline 5 & $\begin{array}{l}\text { I feel there is a missing course which is not taught in the } \\
\text { class and I think the course is important for my future } \\
\text { profession and internship program }\end{array}$ & 33 & 42 & 16 & 4 & 3 \\
\hline
\end{tabular}

Based on the counting result, it was found that the value for those who chose strongly agree was 150 . The value for those who chose to agree was 206. The value for those who chose neutral was 117 . The value for those who chose to disagree was 51 . The value for those who chose strongly

137 | IJET| Volume. 10, Issue 2. December 2021 Copyright 2021 Ainun Fikria, Akhyat Hilmi, and Afita Prastiwi are licensed under Creative Commons AtrributionShareAlike 4.0 International License 
disagree was 11. All those results are counted and the total score is 1813 with counted score interpretation follows:

$\mathrm{Y}=$ the highest score of Likert $\mathrm{x}$ total respondent $\mathrm{x}$ total response

$=5 \times 98 \times 5=2450$

$\mathrm{X}=$ the lowest score of Likert $\mathrm{x}$ total respondent $\mathrm{x}$ total response

$=1 \times 98 \times 5=490$

Percentage formula $\%=$ Total Score $/$ Y x $100=1813 / 2450$ x $100=74 \%$ (agree). From the value obtained, it is concluded that the students' response toward a predicting factor of school well-being is 'agree'. It means most students really experience the predicting factors of school well-being stated during their study time at PPI Madiun. Among the five predicting factors that serve as influencing factors of school well-being, most students agree that their study at PPI Madiun opens a big opportunity to improve their skill which reflects that most students have a high academic efficacy.

This dimension has the lowest percentage compared to two other dimensions. From three negative predicting factor (item 2,4,5) the experience related to subject course has gained attention from the teacher. According teacher 1, this point may be experienced by the alumni because experience the curriculum redesigned taken after that period.

The next negative prediction factor of school well-being is related to students' feeling overwhelming during study time. Similar to the information from the teacher about physical activity which affects the class.

\section{Emotional well being}

From the emotional well-being dimension questionnaire part, the students' responses toward the seven prediction factors measured using Likert scale are presented as follows.

Table 3.2. The Result of Emotional Well-Being Questionnaire

\begin{tabular}{clccccc}
\hline No & \multicolumn{1}{c}{ Question } & SA & A & N & D & SD \\
1 & I am fully focused at my studies & 7 & 54 & 31 & 6 & 1 \\
2 & I am extremely motivated to study harder in all subjects & 27 & 42 & 25 & 3 & 1 \\
3 & I am very motivated to study harder in certain subjects & 33 & 49 & 10 & 3 & 3 \\
4 & My desire to work professionally comes every day & 37 & 44 & 14 & 2 & 1 \\
5 & $\begin{array}{l}\text { I believe all skills that I gained from PPI will lead my career } \\
\text { in the future }\end{array}$ & 43 & 44 & 9 & 1 & 1 \\
6 & $\begin{array}{l}\text { I think I can carry the PPI vision and implement it in the } \\
\text { future }\end{array}$ & 25 & 58 & 13 & 1 & 1 \\
7 & I believe I will get a job which relevant to my major & 48 & 37 & 9 & 3 & 1 \\
\hline
\end{tabular}

Based on the counting result, it was found that the value for those who chose strongly agree was 220. The value for those who chose to agree was 328. The value for those who chose neutral was 110 . The value for those who chose to disagree was 19. The value for those who chose strongly

137 | IJET| Volume. 10, Issue 2. December 2021 Copyright 2021 Ainun Fikria, Akhyat Hilmi, and Afita Prastiwi are licensed under Creative Commons AtrributionShareAlike 4.0 International License 
disagree was 11. All those results are counted and the total score is 2789 with counted score interpretation follows:

$\mathrm{Y} \quad=$ the highest score of Likert $\mathrm{x}$ total respondent $\mathrm{x}$ total response

$=5 \times 98 \times 7=3430$

$\mathrm{X}=$ the lowest score of Likert $\mathrm{x}$ total respondent $\mathrm{x}$ total response

$=1 \times 98 \times 7=686$

Percentage formula $\%=$ Total Score $/$ Y x $100=2789 / 3430$ x $100=81,3 \%$ (strongly agree). From the value obtained, it is concluded that the students' response toward predicting the factor of emotional well-being is at the 'strongly agree' level. It means most students really experience the predicting factors of emotional well-being stated during their study time at PPI Madiun. Among the seven predicting factors served as influencing factors of school emotional being, most students believe that the skills that they learn during the study time at PPIM will lead their career in the future. This reflect that most students have a high self-efficacy.

This dimension has the highest percentage among the three dimensions of student wellbeing in this study. From the table, it can be seen that most students are highly motivated either at school or when they do an internship. This high motivation may because the students think the outcome of their activity is interesting, useful and important (Parhiala et al, 2018). Motivation In this case, referring to the previous predicting factors, the students' self-efficacy and academics turn out to be the source of motivation.

The other predicting factor is related to the emotional domain, is the students' ability to focus. Although $7 \%$ students are extremely sure to see themselves to be able to focus on studying, about $30 \%$ students feel unsure that they can focus during studying. The difficulty to focus can be caused by lack of sleep, fatigue or anxiety. Referring to the information from the interview with the teacher that students sometimes feel sleepy in the classroom because PPIM holds many physical activities from early morning until evening, the students' experience having difficulty to focus during studying is confirmed.

\section{Social Well Being}

From the social well-being dimension questionnaire part, the students' responses toward the three prediction factors measured using Likert scale are presented as follows:

Table 3.2. The Result of Social Well-Being Questionnaire

\begin{tabular}{clccccc}
\hline No & \multicolumn{1}{c}{ Question } & SA & A & N & D & SD \\
1 & My learning process is always appreciated & 24 & 49 & 24 & 1 & 0 \\
2 & $\begin{array}{l}\text { I feel that my dedication and work is highly } \\
\text { appreciated }\end{array}$ & 20 & 42 & 30 & 4 & 1 \\
3 & my friends always support me & 50 & 39 & 6 & 1 & 1 \\
\hline
\end{tabular}

Based on the counting result, it was found that the value for those who chose strongly agree was 94. The value for those who chose to agree was 130. The value for those who chose neutral

137 | IJET| Volume. 10, Issue 2. December 2021 Copyright 2021 Ainun Fikria, Akhyat Hilmi, and Afita Prastiwi are licensed under Creative Commons AtrributionShareAlike 4.0 International License 
was 60. The value for those who chose to disagree was 6 . The value for those who chose strongly disagree was 2. All those results are counted and the total score is 1184 with counted score interpretation follows:

$\mathrm{Y} \quad=$ the highest score of Likert $\mathrm{x}$ total respondent $\mathrm{x}$ total response

$=5 \times 98 \times 3=1470$

$\mathrm{X}=$ the lowest score of Likert $\mathrm{x}$ total respondent $\mathrm{x}$ total response

$=1 \times 98 \times 3=294$

Percentage formula $\%=$ Total Score $/$ Y x $100=1184 / 1470$ x $100=80,5 \%$ (strongly agree). Therefore, the result of students' response toward social well-being is 'strongly agree'. It means most students have a very good response toward social well-being.

From the value obtained, it is concluded that the students' response toward predicting factor of social well-being is at the 'strongly agree' level. It means most students really experience the predicting factors of social well-being stated during their study time at PPI Madiun. Among the three predicting factors that served as influencing factors of school emotional being, most students believe that their friends always supporting them during the study time at PPIM will lead their career in the future. This reflects the predicting factor 'support'.

The explanation above brings us to the conclusion that generally the students' well-being of PPIM cadets is good. It can be seen from the relatively high percentage of each dimension based on students' subjective tests. This condition is confirmed by the evaluation of the staff. The staff perceive the students of PPIM have a mental strength and good attitude.

The strong predicting positive factors of SBW are student motivation, academic and selfefficacy and support from friends. The item that serves as a negative predicting factor of SWB is related to school well-being dimension. It can be noticed as well that some predicting factors may influence other factors such as. The similar finding of a well-being factor networking (Govorova et.al, 2020)

The result presented above, also reveals how the emotional and social state of the student and how their environment -in this case school- influenced their learning process. The interventions for reducing the likelihood of negative well-being occurring is described below. The obvious negative factors related to what students experience in internship, concerning the subject course. An alumnus who is now working for a railway operator, and it was informed that he was quick to adapt to the new driving system on MRT. Responding to this matter, PPIM conducts regular either internal evaluation or external evaluation involving stakeholders.

One of the teachers admitted that the institution has not been able to afford a particular training machine yet because of its high expense. Yet, according to her, this obstacle is overcome by giving the chance to the student to do the internship in the company that has the latest technology so that the student can learn and practice using the newest technology possible. In the evaluation session with stakeholders, it is obtained that the students adapted quickly with the new equipment used because the students had already mastered the basic skill very well. PPIM also

137 | IJET| Volume. 10, Issue 2. December 2021 Copyright 2021 Ainun Fikria, Akhyat Hilmi, and Afita Prastiwi are licensed under Creative Commons AtrributionShareAlike 4.0 International License 
conducted curriculum design with the stake holder involved to ensure that student gets the up dated knowledge that they need at the workplace.

Another negative factor is concerning students' focus in studying. To overcome this problem. Teacher 2 suggested, as a teacher she had to pay more attention to the students, created conducive classroom and applied appropriate method such as joyful learning. Those steps in line with the study on SWB intervention as Flinchbaugh, C. L., et al. (2012) stated upwards.

\section{CONCLUSION}

Students' well-being is one important indicator in evaluating whether the education process is on the right track. The quality of student well-being in an emotional, social and school dimension of a student of PPIM is relatively in good level. The influence of this good state of well-being affected student performance particularly in the workplace. Derived from the result of the study, the main factors influencing student's well-being which affects educational outcomes are academic efficacy, self-efficacy and support from their friends.

Hence, with the tight schedule and tough physical activity, the institution should pay attention on a psychological aspect. Students' daily activity on the dormitory relatively starts early in the morning then continue the learning process at school time. The activity still continued later in the evening. The activities are ranging from exercising, studying, co-curricular activity, extracurricular activity, actually positive ones, aiming to maintain and increase students' hard skills and soft skills. Although rarely students are reported to ask for counseling to the counseling division, those burdens are potential generate stress on students which may lead to negative impact and release. With only two counselors handling about 600 students, it is difficult to do quick prevention, particularly in managing stress, anxiety and the other behavioral problem.

\section{References}

Abd Majid, M. Z., Hussin, M., Norman, M. H., \& Kasavan, S. (2020). The employability skills among students of Public Higher Education Institution in Malaysia. GeografiaMalaysian Journal of Society and Space, 16(1).

Arslan, G. and M. Coşkun (2020). Student subjective wellbeing, school functioning, and psychological adjustment in high school adolescents: A latent variable analysis. Journal of Positive School Psychology 4(2): 153-164

Boahin, P., \& Hofman, A. (2013). A disciplinary perspective of competency-based training on the acquisition of employability skills. Journal of Vocational Education \& Training, 65(3), 385-401.

Borgonovi, F. and J. Pál (2016). A framework for the analysis of student well-being in the PISA 2015 study: Being 15 in 2015.

Dacey, J. S., et al. (2016). Your Child's Social and Emotional Well-being: A Complete Guide for Parents and Those who Help Them, John Wiley \& Sons.

Dewi, L. and N. Nasywa (2019). "Faktor-faktor yang mempengaruhi subjective well-being."

137 | IJET| Volume. 10, Issue 2. December 2021

Copyright 2021 Ainun Fikria, Akhyat Hilmi, and Afita Prastiwi are licensed under Creative Commons AtrributionShareAlike 4.0 International License 
Jurnal Psikologi Terapan dan Pendidikan 1(1): 54-62.

Flinchbaugh, C. L., et al. (2012). Student well-being interventions: The effects of stress management techniques and gratitude journaling in the management education classroom. Journal of Management Education 36(2): 191-219.

Govorova, E., et al. (2020). How schools affect student well-being: a cross-cultural approach in 35 OECD countries. Frontiers in psychology 11: 431.

Gutman, L.M., Brown, J., Akerman, R., \& Obolenskaya, P. (2009). Well-being from childhood to adolescence: risk and protective factors. London: DCSF.

Gutman, L.M. \& Feinstein, L. (2008). Pupil and school effects on children's well-being. London.

Hagenauer, G., \& Hascher, T. (2014). Early adolescents' enjoyment in learning situations at school and its relation to student achievement. Journal of Education and Training Studies, 2(2), 20-30. http://dx.doi.org/10.11114/jets.v2i2.254.

Hartati, S. and R. Anugrahwati (2019). "Faktor-Faktor Yang Mempengaruhi Prestasi Akademik Belajar Mahasiswa Tingkat III di Akademi Keperawatan Manggala Husada Jakarta: Prestasi Belajar, Pembelajaran." Jurnal Ilmiah Keperawatan Altruistik 2(1): 28-40.

Holmes, L. (2013). Competing perspectives on graduate employability: possession, position or process?. Studies in higher education, 38(4), 538-554.

Isnurani, I., et al. (2021). "Faktor Yang Mempengaruhi Prestasi Akademik Mahasiswa Universitas Pamulang (Studi Kasus Mahasiswa Prodi Matematika Fmipa)." APOTEMA: Jurnal Program Studi Pendidikan Matematika 7(1): 47-55.

KIRANA, A. (2016). Faktor-Faktor yang Mempengaruhi Prestasi Akademik Mahasiswa, Universitas Gadjah Mada.

Konu, A. and M. Rimpelä (2002). Well-being in schools: a conceptual model. Health promotion international 17(1): 79-87.

Merriam, S. B. (1988). Case study research in education: A qualitative approach. San Francisco: Jossey-Bass.

Morse, J. M., \& Chung, S. E. (2003). Toward holism: The significance of methodological pluralism. International Journal of Qualitative Methods, 2(3), 13-20.

OECD (2015). Skills for Social Progress

OECD (2017). PISA 2015 Results (Volume III)

Purtaghi, G., \& Pakpour, A. (2014). Happiness, self-efficacy and academic achievement among students of baqiyatallah university of medical sciences. Journal of medical education development, 7(13), 45-56.

Pollard, E. L. and P. D. Lee (2003). Child well-being: A systematic review of the literature.Social indicators research 61(1): 59-78.

Prapdopo, P. and F. Fariyanti (2016). "Analisis Beberapa Faktor Yang Mempengaruhi Prestasi Akademik Mahasiswa." Jurnal Eksis 12(1).

Putri, S., et al. (2019). Subjective well-being berhubungan dengan prestasi akademik mahasiswa program studi ilmu keperawatan. Jurnal Keperawatan 11(4): 243-250.

137 | IJET| Volume. 10, Issue 2. December 2021

Copyright 2021 Ainun Fikria, Akhyat Hilmi, and Afita Prastiwi are licensed under Creative Commons AtrributionShareAlike 4.0 International License 
Quinn, P. D., \& Duckworth, A. L. (2007). Happiness and academic achievement: Evidence for reciprocal causality. In The Annual Meeting of the American Psychological Society (Vol. 24, No. 27.5, p. 2007).

Rahmayani, D. (2017). "Faktor-faktor yang mempengaruhi konsentrasi belajar pada Mahasiswa Program Studi Ilmu Keperawatan Universitas Muhammadiyah Yogyakarta." Universitas Muhammadiyah Yogyakarta.

Rulanggi, R., et al. (2021). Faktor-Faktor yang Memengaruhi Subjective Well-Being pada Mahasiswa. Seminar Nasional Psikologi UM.

Schulze, S. (2003). Views on the combination of quantitative and qualitative research approaches. Progressio, 25(2), 8-20.

Schutte, N. S., et al. (2002). Characteristic emotional intelligence and emotional well-being. Cognition \& Emotion 16(6): 769-785.

Stake, R. E. (1995). The art of case study research. Thousand Oaks: Sage Publications.

Tabbodi, M., Rahgozar, H., \& Makki Abadi, M. M. (2015). The relationship between happiness and academic achievements. European Online Journal of Natural and Social Sciences: Proceedings, 4(1 (s)), pp-241.

Terrell, S. R. (2012). Mixed-methods research methodologies. The qualitative report, 17(1), 254280.

Tian, L., et al. (2015). Development and validation of the brief adolescents' subjective well-being in school scale (BASWBSS). Social indicators research 120(2): 615-634.

TL, D. I., et al. (2017). "Faktor-Faktor Yang Mempengaruhi Prestasi Akademik: Studi Kasus Pada Mahasiswa Program Studi Akuntansi Universitas Semarang." Jurnal Dinamika Sosial Budaya 18(1): 39-48.

Wright, B., \& Schwager, P. H. (2008). Online survey research: can response factors be improved?. Journal of Internet Commerce, 7(2), 253-269.

Yang, Q., et al. (2019). Relations among academic achievement, self-esteem, and subjective wellbeing in school among elementary school students: A longitudinal mediation model. School Psychology 34(3): 328.

Yin, R. K. (2003). Case study research: Design and methods. Thousand Oaks, Calif: Sage Publications.

You, S., et al. (2014). Further validation of the Social and Emotional Health Survey for high school students. Applied Research in quality of life 9(4): 997-1015.

Yusof, N., \& Jamaluddin, Z. (2017). Graduate employability and preparedness: A case study of University of Malaysia Perlis (UNIMAP), Malaysia. Geografia-Malaysian Journal of Society and Space, 11(11).

Zhang, D. C. and T. L. Renshaw (2020). Personality and college student subjective wellbeing: A domain-specific approach. Journal of Happiness Studies 21(3): 997-1014.

137 | IJET| Volume. 10, Issue 2. December 2021

Copyright 2021 Ainun Fikria, Akhyat Hilmi, and Afita Prastiwi are licensed under Creative Commons AtrributionShareAlike 4.0 International License 